\title{
Determinan Kadar Cluster Diferensiasi 4 (CD4) pada Orang dengan HIV/AIDS
}

\section{Determinants of Cluster Differentiation 4 (CD4) Levels in People With HIVIAIDS}

\author{
Rico Januar Sitorus ${ }^{1}$, Chairil Anwar ${ }^{2}$, Imelda Purba ${ }^{3}$, Merry Natalia ${ }^{4}$ \\ ${ }^{1,3}$ Fakultas Kesehatan Masyarakat, Univeristas Sriwijaya, Indonesia \\ ${ }^{2}$ Fakultas Kedokteran, Universitas Sriwijaya, Indonesia \\ ${ }^{4}$ Kantor Kesehatan Pelabuhan Palembang, Indonesia
}

\section{ARTICLE INFO}

\section{Article history}

Received date

01 Mar 2021

Revised date

26 Mar 2021

Accepted date

23 Apr 2021

\section{Keywords:}

CD4 levels;

Duration of treatment;

HIV-AIDS;

Stigma;

Side effects.

\section{Kata kunci:}

Kadar CD4;

Lama pengobatan;

HIV-AIDS;

Stigma;

Efek samping.

\section{ABSTRACT/ ABSTRAK}

\begin{abstract}
AIDS which is caused by the human immunodeficiency virus (HIV), is a global health crisis, with differentiated cluster 4 (CD4) cells being the main target so that it can affect the high morbidity and mortality rates. This study aimed to determine the determinants that affect CD4 levels in people with HIV/AIDS. The study population was all people with HIV/AIDS in care, support, and treatment (CST) services in Palembang City with a sample size of 118 . The sampling technique was carried out using nonrandom, namely purposive sampling. Samples were taken when respondents took antiretroviral (ARV) treatment at a health facility. The research instrument used a structured questionnaire and medical records. To measure the determinant (independent variable) was done by interview, while to determine the CD4 count using data that has been recorded in the Medical Record. The results are the length of treatment was a factor that could reduce the risk of low CD4 levels in people with HIV/AIDS, with p-value $=0,006$; ORAdj 0,286 $(0,117-0,697)$, whereas stigma and treatment side effects were proven as confounding variables. Increasing the CD4 in people living with HIV/AIDS requires appropriate and regular treatment. Regular treatment with a duration of therapy of more than 1 year has been shown to prevent low CD4 cells. The higher the CD4 cell count in people living with HIV/AIDS, the greater the chance of controlling opportunistic infections, reducing transmission and premature death. People with HIV/AIDS are advised to take regular medication at available health facilities and take medication regularly.
\end{abstract}

AIDS yang disebabkan oleh human immunodeficiency virus (HIV), adalah krisis kesehatan global, dengan sel cluster diferensiasi 4 (CD4) menjadi target utama sehingga dapat mempengaruhi tingkat kesakitan dan kematian yang tinggi. Tujuan penelitian untuk mengetahui determinan yang mempengaruhi kadar CD4 pada orang dengan HIV/AIDS. Populasi penelitian adalah seluruh orang dengan HIV/AIDS dilayanan care, support, and treatment (CST) di Kota Palembang dengan jumlah sampel 118. Teknik sampling dengan non-random yaitu purposive sampling. Sampel diambil saat responden melalukan pengobatan antiretroviral (ARV) di fasilitas kesehatan. Instrumen penelitian menggunakan kuesioner terstruktur dan rekam medis. Untuk mengukur determinan (variabel independen) dilakukan dengan wawancara, sedangkan untuk mengetahui jumlah CD4 menggunakan data yang sudah tercatat di Rekam Medis. Hasil penelitian menunjukkan bahwa lama pengobatan menjadi faktor yang dapat menurunkan risiko rendahnya kadar CD4 pada Orang dengan HIV/AIDS, dengan $p$-value $=0,006$; ORAdj 0,286 (0,117-0,697), sedangkan stigma dan efek samping pengobatan terbukti sebagai variabel confounding. Untuk meningkatkan CD4 pada orang dengan HIV/AIDS, diperlukan pengobatan yang tepat dan teratur. Pengobatan yang teratur dengan lama terapi lebih 1 tahun terbukti dapat mencegah rendahnya CD4. Semakin tinggi CD4 pada Orang dengan HIV/AIDS, semakin besar peluang mengendalikan infeksi opportunistik, menekan penularan dan kematian dini. Orang dengan HIV/AIDS disarankan melakukan pengobatan yang teratur di fasilitas kesehatan yang tersedia dan meminum obat secara teratur.

\footnotetext{
Corresponding Author:
}

Rico Januar Sitorus

Fakultas Kesehatan Masyarakat, Univeristas Sriwijaya, Indonesia

Email: rico_januar@fkm.unsri.ac.id 


\section{PENDAHULUAN}

Saat ini salah satu tantangan penanganan epidemi Acquired Immune Deficiency Syndrome (AIDS) adalah pengendalian infeksi oportunistik, stigma dan diskriminasi yang diterima orang dengan HIV/AIDS (ODHA). Sampai saat ini belum ada obat untuk infeksi human immunodeficiency virus (HIV), tetapi terapi antiretroviral (ARV) yang efektif dapat mengendalikan virus dan membantu mencegah penularan selanjutnya ke orang lain. Per 2 desember hanya 12 negara yang mengadopsi rekomendasi World Health Organization (WHO) untuk memulai antiretroviral (ARV) pada semua orang yang hidup dengan HIV/AIDS terlepas dari jumlah CD4 (WHO, 2020).

Salah satu target tujuan pembangunan berkelanjutan (SDGs) adalah mengakhiri epidemi HIV/AIDS pada tahun 2030 (Joint, 2014). HIV/AIDS terus menjadi masalah kesehatan masyarakat global yang telah merenggut hampir 33 juta nyawa dan diperkirakan ada 38 juta orang yang hidup dengan HIV/AIDS pada akhir 2019 (WHO, 2020). Indonesia merupakan salah satu negara di dunia dengan epidemi HIV/AIDS masih tinggi yang terkonsentrasi pada populasi kunci seperti pekerja seks dan pelangannya, pengguna narkotika psikotropika dan zat adiktif lainnya, NAPZA suntik (penasun), lelaki seks dengan lelaki (LSL) dan waria. Indonesia dengan wilayah yang luas dan sebagai negara kepulauan memiliki pola epidemi yang dinamis dan kompleks. Pada tahun 2015, diperkirakan jumlah orang dengan HIV/AIDS (ODHA) sekitar 630.000. Prevalensi HIV/AIDS pada tingkat Nasional untuk kelompok usia 15-49 tahun ke atas diperkirakan mencapai 0,3\%. Indonesia sempat mengalami peningkatan kematian ibu setelah di tahun 2007 dengan 228 per 100.000 kelahiran hidup (WHO, 2017).

Pada tahun 2019, 68\% orang dewasa dan 53\% anak-anak yang hidup dengan HIV secara global menerima terapi antiretroviral (ARV) seumur hidup, $85 \%$ ibu hamil dan menyusui yang hidup dengan HIV juga menerima ARV, yang tidak hanya melindungi kesehatan mereka, tetapi juga memastikan pencegahan penularan HIV ke bayi mereka (WHO, 2020).

AIDS merupakan tahap akhir perkembangan penyakit dari infeksi HIV yang menyebabkan kerusakan sistem kekebalan tubuh (Mirzaei, et al., 2013). Menelusuri HIV/AIDS dengan cepat dan menetapkan target sangat penting untuk mengakhiri epidemi AIDS. Menghentikan epidemi AIDS pada tahun 2030 berarti AIDS tidak lagi menjadi ancaman kesehatan masyarakat. Ini berarti bahwa penyebaran HIV telah dikendalikan. Penekanan penularan dapat meningkatkan harapan hidup, peningkatan produktivitas dan pengurangan biaya seiring dengan berkurangnya dampak AIDS (Joint United Nations Programme on HIV/AIDS, 2014). Pencegahan HIV mencapai target 90-9090 pada tahun 2020, yaitu $90 \%$ dari semua orang yang hidup dengan HIV mengetahui status HIV mereka, 90\% orang dengan diagnosis HIV menerima terapi antiretroviral (ARV) dan 90\% dari semua orang yang memakai pengobatan HIV mencapai penekanan virus (Sidibé, et al., 2016).

Infeksi HIV adalah penyakit kronis yang ditandai dengan replikasi virus yang berkelanjutan dan kerusakan limposit $\mathrm{T}$ cluster diferensiasi 4 (CD4) (Aubert, et al., 2011). Tingkat imunosupresi berkaitan langsung dengan jumlah CD4 dan T-limposit (Edathodu, et al., 2009). Jumlah CD4 merupakan indikator perkembangan penyakit HIV yang digunakan secara teratur dalam memantau infeksi (Maartens, et al., 2014). CD4 per tahun akan menurun rata-rata sekitar 100 yang kemudian diikuti dengan penurunan kondisi klinis pasien. Tingkat CD4 ini juga dapat dipantau untuk mengetahui sistem kekebalan tubuh, menentukan kapan memulai terapi antiretroviral,dan memantau kemajuan pengobatan (WHO, 2016).

Saat ini banyak ODHA dengan kadar CD4 yang rendah dan mengakibatkan tingginya infeksi oportunistik yang dialami. Untuk mencegah infeksi yang lebih parah, penderita HIV harus meningkatkan kadar CD4 nya. Salah cara untuk meningkatkan kadar CD4 adalah dengan melakukan pengobatan yang teratur melalui terapi antoretoviral. Sampai saat ini, masih banyak ODHA belum memanfaatkan pengobatan ini dengan baik. Organisasi Kesehatan dunia (WHO) merekomendasikan untuk melakukan terapi antiretroviral (ARV) sejak dini. Pengobatan yang tepat dapat meningkatkan CD4, mengurangi penularan, mencegah infeksi opportunistik, penurunan infeksi HIV baru dan kematian dini (Montaner, et al., 2014; WHO, 2015). Tujuan dari penelitian ini adalah untuk mengetahui determinan kadar cluster diferensiasi 4 (CD4) pada orang dengan HIV/AIDS di Kota Palembang.

\section{METODE}

Penelitian observasional dilakukan dengan desain crossectional. Populasi penelitian adalah seluruh ODHA dilayanan CST di Kota Palembang dengan jumlah sampel 118. Teknik 
sampling dilakukan adalah dengan non random yaitu purposive sampling. Sampel diambil saat ODHA melalukan pengobatan ARV di fasilitas kesehatan. Penelitian dilakukan di Rumah Sakit dan Puskesmas yang menerima layanan Kesehatan pada ODHA di Kota Palembang, Sumatera Selatan. Penelitian dilakukan pada bulan Februari sampai Maret 2020. Instrumen penelitian menggunakan kuesioner terstruktur dan rekam medis. Untuk mengukur determinan (variabel independen) dengan wawancara, sedangkan untuk mengetahui jumlah CD4 menggunakan data yang sudah tercatat di Rekam Medis.

Data penelitian dianalisis secara deskriptif, bivariat dan multivariat. Analisis deskriptif bertujuan untuk mengetahui distribusi frekuensi untuk data karakteristik subyek yang meliputi semua variabel independen. Analisis bivariat bertujuan untuk melihat hubungan antara masingmasing variabel independen yang diteliti dengan variabel dependen dengan jenis uji statistik digunakan adalah uji chi-square test. Nilai kemaknaan untuk menjawab hipotesis adalah jika tingkat kesalahan pada alpha 5\% dan nilai confidence interval ditetapkan 95\%. Analisis multivariat bertujuan untuk mengetahui variabel independen yang paling besar pengaruhnya terhadap variabel dependen. Uji yang digunakan dalam analisis ini adalah regresi logistik dengan variabel dependen berupa data katagorik.

Penelitian ini telah melewati kaji etik dan mendapatkan Keterangan Lolos Kaji Etik dengan Nomor 411/UN9.1.10/KKE/2020 dari Komisi Etik Penelitian Kesehatan Fakultas Kesehatan Masyarakat Universitas Sriwijaya.

\section{HASIL}

Tabel 1. Karakteristik Responden

\begin{tabular}{lrr}
\hline \multicolumn{1}{c}{ Karakteristik } & n & \multicolumn{1}{c}{$\%$} \\
\hline Jenis kelamin & & \\
Laki-laki & 93 & 78,8 \\
Perempuan & 25 & 21,2 \\
Pendidikan & & \\
Tamat SD & 11 & 9,3 \\
Tamat SMP & 7 & 5,9 \\
Tamat SMA & 65 & 55,1 \\
Tamat Perguruan Tinggi & 35 & 29,7 \\
Status pernikahan & & \\
Menikah & 46 & 39,0 \\
Belum menikah & 60 & 50,8 \\
Janda & 7 & 5,9 \\
Duda & 5 & 4,2 \\
Pekerjaan & & \\
PNS & 6 & 5,1 \\
Pegawai swasta & 34 & 28,8 \\
Wiraswasta & 39 & 33,1 \\
Buruh & 9 & 7,6 \\
Pelajar/Mahasiswa & 7 & 5,9 \\
Ibu Rumah Tangga & 18 & 15,3 \\
Tidak bekerja & 5 & 4,2 \\
\hline
\end{tabular}

Hasil penelitian menunjukkan bahwa mayoritas responden berjenis kelamin laki-laki (78,8\%). Berdasarkan tingkat pendidikan, responden memiliki riwayat pendidikan yang ditamatkan beragam mulai dari tamat sekolah dasar sampai tamat perguruan tinggi dengan tingkat Pendidikan yang ditamatkan lebih banyak adalah tamat SMA $(55,1 \%)$. Berdasarkan status pernikahan, karakteristik status pernikahan responden mayoritas reponden belum menikah $(50,8 \%)$. Berdasarkan karakteristik pekerjaan, jenis pekerjaan responden beragam dengan pekerjaan yang paling banyak sebagai wiraswasta $33,1 \%$.

Tabel 2. Analisis Bivariat

\begin{tabular}{|c|c|c|c|c|c|c|}
\hline \multirow{3}{*}{ Variabel } & \multicolumn{4}{|c|}{ Kadar CD4 (cells/mm³) } & \multirow{3}{*}{$p$-value } & \multirow{3}{*}{ Nilai OR $(95 \% \mathrm{CI})$} \\
\hline & \multicolumn{2}{|c|}{$<500$} & \multicolumn{2}{|c|}{$>=500$} & & \\
\hline & $\mathbf{n}$ & $\%$ & $\mathbf{n}$ & $\%$ & & \\
\hline Lama Pengobatan (Tahun) & & & & & 0,009 & $0,328(0,271-0,776)$ \\
\hline$<1$ & 20 & 25,9 & 14 & 8,1 & & \\
\hline$>=1$ & 70 & 64,1 & 14 & 19,9 & & \\
\hline Stigma & & & & & 0,564 & $0,675(0,232-1,964)$ \\
\hline Ya & 14 & 15,3 & 6 & 4,7 & & \\
\hline Tidak & 76 & 74,7 & 22 & 23,3 & & \\
\hline Efek Samping & & & & & 0,689 & $0,667(0,205-2,165)$ \\
\hline $\mathrm{Ya}$ & 72 & 73,2 & 24 & 22,8 & & \\
\hline Tidak & 18 & 16,8 & 4 & 5,2 & & \\
\hline Dukungan Keluarga & & & & & 0,488 & $0,598(0,204-1.750)$ \\
\hline Rendah & 66 & 67,9 & 23 & 21,1 & & \\
\hline Tinggi & 24 & 22,1 & 5 & 6,9 & & \\
\hline Kepatuhan berobat & & & & & 0,877 & $0,793(0,277-2,270)$ \\
\hline Tidak & 16 & 16,8 & 6 & 5,2 & & \\
\hline $\mathrm{Ya}$ & 74 & 73,2 & 22 & 22,8 & & \\
\hline Infeksi Opportunistik & & & & & 0,811 & $1,250(0,493-3,167)$ \\
\hline $\mathrm{Ya}$ & 30 & 29,0 & 8 & 9,0 & & \\
\hline Tidak & 60 & 61,0 & 20 & 19,0 & & \\
\hline
\end{tabular}


Berdasarkan tabel 2, lama terapi berhubungan dengan jumlah CD4 orang dengan HIV/AIDS (ODHA) dengan $p$-value 0,009<alpha $(0,05)$ dan nilai ORcrude $(95 \% \mathrm{CI}): 0,328(0,271$ $0,776)$. Sedangkan variabel stigma, efek samping pengobatan, dukungan keluarga, kepatuhan berobat dan adanya infeksi opportuinistik tidak berhubungan.

Tabel 3. Analisis Multivariat

\begin{tabular}{llcrr}
\hline Variabel & & $\begin{array}{c}\text { Koefisien } \\
\text { Beta }\end{array}$ & $\begin{array}{c}\boldsymbol{p} \text { - } \\
\text { value }\end{array}$ & $\begin{array}{c}\text { Nilai OR } \\
(\mathbf{9 5 \%} \text { CI })\end{array}$ \\
\hline Lama & $<1$ & & & 0,286 \\
Pengobatan & $>=1$ & $-1,253$ & 0,006 & $(0,117-$ \\
(Tahun) & (reff) & & & $0,697)$ \\
& Ya & & & 0,501 \\
Stigma & Tidak & $-0,692$ & 0,232 & $\begin{array}{r}(0,161- \\
\text { (reff) }\end{array}$ \\
& Ya & & & $1,557)$ \\
Efek & Tidak & 0,09 & 0,893 & 1.095 \\
Samping & (reff) & & & $4,293-$ \\
& & & & \\
\hline
\end{tabular}

Hasil analisis multivariat pada tabel 3 menunjukkan bahwa lama terapi berhubungan secara signifikan terhadap jumlah CD4 ODHA dengan $p$-value $0,006<a l p h a(0,05)$, dan nilai ORAdj $0,286 \quad(0,117-0,697)$. Hal ini menunjukkan bahwa lama terapi dapat memproteksi atau menurunkan risiko rendahnya jumlah CD4 pada ODHA. Hasil penelitian ini menunjukkan bahwa stigma dan efek samping merupakan faktor perancu (confounding) dalam jumlah CD4 pada ODHA. Hal ini menunjukkan bahwa stigma dan efek samping mempengaruhi kemurnian hubungan antara lama terapi dengan jumlah CD4 ODHA.

\section{PEMBAHASAN}

Cluster of differentiation 4 (CD4) adalah sel darah putih yang berperan penting dalam sistem kekebalan tubuh. Jumlah kadar CD4 memberikan indikasi dan membantu diagnosis terhadap kondisi kesehatan sistem kekebalan, sistem pertahanan alami tubuh yang berguna melawan patogen, infeksi, dan penyakit. Jumlah CD4 memiliki implikasi klinis dan dikaitkan dengan kategori penyakit AIDS dan tidak AIDS (Anglaret, et al., 2012; Young, et al., 2012).

Orang dengan HIV/AIDS (ODHA) harus melakukan pengobatan teratur minimal 1 tahun atau lebih untuk mencegah rendahnya kadar CD4. Hasil penelitian ini menunjukkan bahwa lama pengobatan lebih dari 1 tahun terbukti dapat menurukan risiko rendahnya kadar CD4 ODHA. Pengobatan yang berhasil dapat menekan virus sampai ke tingkat yang tidak terdeteksi. Dengan menekan jumlah virus di dalam tubuh, orang yang terinfeksi HIV/AIDS dapat hidup lebih lama namun mereka tetap dapat menularkan virus dan harus terus menerus mengonsumsi obat antiretroviral untuk menjaga kualitas kesehatannya (Huo, et al., 2016).

Hasil penelitian ini sejalan dengan penelitian Han (2020), hanya $10 \%$ yang gagal memulihkan CD4 setelah menjalani 3 tahun pengobatan dan dipengaruhi dengan faktor usia (Han, et al., 2020). WHO merekomendasikan terapi antiretroviral (ARV) untuk semua orang dengan HIV berapapun jumlah CD4 nya, dan perlu dukungan agar patuh dalam menjalani pengobatan (WHO, 2013). Penurunan kadar CD4 dapat meningkatkan terjadinya infeksi oportunistik (Jamil, 2014). WHO merekomendasikan nilai ambang batas $\mathrm{CD} 4 \leq 500$ untk memulai terapi antiretroviral (WHO, 2013).

Highly Active Antiretroviral Therapy (HAART) diharapkan dapat meningkatkan kadar CD4 pada penderita HIV/AIDs. Kenaikan CD4 penderita HIV/AIDS yang menjalani pengobatan 6 bulan pertama diperngaruhi oleh kepatuhan berobat dan adanya infeksi opportunistik seperti TB Paru (Rusconi, 2017; Yogani, et al., 2015). Faktor lain yang berhubungan dengan tingkat CD4 adalah indeks massa tubuh, jenis kelamin, kebiasaan merokok, usia dan faktor lingkungan seperti paparan pathogen dan penyakit akut. (Malaza, et al., 2013).

Hasil penelitian ini menunjukkan bahwa stigma merupakan faktor perancu atau confounding terhadap determinan kadar CD4 pada ODHA. Hal ini menunjukkan bahwa stigma berhubungan dengan kadar CD4 orang dengan HIV/AIDS. Stigmatisasi adalah bagian dari pernyataan konservatif atas hubungan kekuasaan, kemiskinan, atau otoritas moral yang bertumpu pada kemampuan untuk mengontrol seksualitas (Campbell, et al., 2007). ODHA masih sering mendapatkan stigma negatif dimasyarakat dan dipercaya dapat mempengaruhi kepatuhan dan keberhasilan pengobatan. Stigma yang diterima ODHA sangat mempengaruhi kondisi psikologis. (Ajong, et al., 2018). Untuk itu, diawal pengobatan diperlukan dukungan dan tidak memberikan stigma negatif. Penanganan Kesehatan mental, interpersonal, dan mekanisme psikososial dapat meningkatkan kepatuhan berobat sehingga dapat mengontrol kadar CD4. (Turan et al., 2016) Masyarakat dan anggota keluarga harus menerima dan mendukung mereka untuk memperoleh hak dan kewajiban yang sama di masyarakat (Turan, et al., 2019).

Stigma yang di dapatkan oleh ODHA dapat menunda dan menggagalkan pencarian 
pengobatan dan kepatuhan berobat. Penundaan pengobatan dan kegagalan kepatuhan dalam berobat sehingga mempengaruhi kadar CD4, dampak pada pelayanan Kesehatan dan menggagagalkan upaya penanggulangan pandemi ini secara global (Famoroti, et al., 2013). Infeksi HIV/AIDS memiliki patogenesis yang sangat kompleks dan bervariasi. Kekhususan patogenesis sering mempersulit pilihan pengobatan yang saat ini tersedia untuk infeksi HIV/AIDS. Hambatan utama yang dihadapi dalam pengobatan ART adalah timbulnya efek samping sehingga dapat mengakibatkan orang berhenti berobat. Pengobatan yang tepat, patuh dan mendapatkan dukungan psikologis dapat menurunkan angka kesakitan dan kematian orang dengan HIV/AIDs (Bhatti, et al., 2016). Gangguan psikologis seperti depresi merupakan gangguan yang sering terjadi pada orang dengan HIV/AIDS apalagi selama menjalani pengobatan (Jagannath, et al., 2011).

Hasil penelitian ini menunjukkan bahwa efek samping pengobatan yag dijalankan ODHA merupakan faktor perancu atau confounding dalam terhadap determinan kadar CD4 pada ODHA. Hal ini menunjukkan bahwa efek samping berhubungan dengan kadar CD4 orang dengan HIV/AIDS. Jenis pengobatan yang biasa dilakukan oleh odha adalah terapi antiretroviral.

\section{DAFTAR PUSTAKA}

Ajong, A. B., Njotang, P. N., Nghoniji, N. E., Essi, M. J., Yakum, M. N., Agbor, V. N., \& Kenfack, B. (2018). Quantification and factors associated with HIV-related stigma among persons living with HIV/AIDS on antiretroviral therapy at the HIV-day care unit of the Bamenda Regional Hospital, North West Region of Cameroon. Globalization and health, 14(1), 56.

Anglaret, X., Minga, A., Gabillard, D., Ouassa, T., Messou, E., Morris, B., Traore, M., Coulibaly, A., Freedberg, K. A., \& Lewden, C. (2012). AIDS and non-AIDS morbidity and mortality across the spectrum of CD4 cell counts in HIVinfected adults before starting antiretroviral therapy in Cote d'Ivoire. Clinical infectious diseases, 54(5), 714-723.

Aubert, R. D., Kamphorst, A. O., Sarkar, S., Vezys, V., Ha, S.-J., Barber, D. L., Ye, L., Sharpe, A. H., Freeman, G. J., \& Ahmed, R. (2011). Antigen-specific CD4 T-cell help rescues exhausted CD8 T cells during chronic viral infection. Proceedings of the National Academy of Sciences, 108(52),
Terapi antiretroviral dapat menurunkan kesakitan, kematian, menekan virus sampai 90\% dan memperpanjang masa hidup ODHA (Gaolathe, et al., 2016; UNAIDS, 2020). Terapi yang dijalankan secara tidak teratur juga berdampak negatif kepada odha karena akan mengalami resistensi obat, membuat intervensi terapeutik di masa depan tidak efektif, sehingga akan berpengaruh terhadap kadar CD4 ODHA (Olem, et al., 2014).

\section{SIMPULAN}

Untuk meningkatkan jumlah cluster of differentiation 4 (CD4) pada ODHA, diperlukan pengobatan yang tepat dan teratur. Pengobatan yang teratur dengan lama terapi lebih 1 tahun terbukti dapat mencegah rendahnya CD4. Semakin tinggi CD4 pada ODHA, semakin besar peluang mengendalikan infeksi opportunistik, menekan penularan dan kematian dini. ODHA disarankan melakukan pengobatan yang teratur di fasilitas kesehatan yang tersedia dan meminum obat secara teratur. Apabila memiliki infeksi opportunistik agar segera melakukan pengobatan yang tepat dan berkonsutasi dengan dokter.

\section{2-21187.}

Bhatti, A. B., Usman, M., \& Kandi, V. (2016). Current scenario of HIV/AIDS, treatment options, and major challenges with compliance to antiretroviral therapy. Cureus, 8(3).

Campbell, C., Nair, Y., Maimane, S., \& Nicholson, J. (2007). Dying Twice' A Multi-level Model of the Roots of AIDS Stigma in Two South African Communities. Journal of health psychology, 12(3), 403-416.

Edathodu, J., Ali, B., \& Alrajhi, A. A. (2009). CD4 validation for the World Health Organization classification and clinical staging of HIV/AIDS in a developing country. International Journal of Infectious Diseases, 13(2), 243-246. https://doi.org/10.1016/j.ijid.2007.12.017

Famoroti, T. O., Fernandes, L., \& Chima, S. C. (2013). Stigmatization of people living with HIV/AIDS by healthcare workers at a tertiary hospital in KwaZulu-Natal, South Africa: a cross-sectional descriptive study. BMC Medical Ethics, 14(1), S6. 
https://doi.org/10.1186/1472-6939-14-S1-S6

Gaolathe, T., Wirth, K. E., Holme, M. P., Makhema, J., Moyo, S., Chakalisa, U., Yankinda, E. K., Lei, Q., Mmalane, M., \& Novitsky, V. (2016). Botswana's progress toward achieving the 2020 UNAIDS 9090-90 antiretroviral therapy and virological suppression goals: a population-based survey. The lancet HIV, 3(5), e221-e230.

Han, W. M., Ubolyam, S., Apornpong, T., Kerr, S. J., Hansasuta, P., Gatechompol, S., Maekanantawat, W., Ruxrungtham, K., Phanuphak, P., Ananworanich, J., \& Avihingsanon, A. (2020). Characteristics of suboptimal immune response after initiating antiretroviral therapy among people living with HIV with a pretreatment CD4 $\mathrm{T}$ cell count $<200$ cells/mm3 in Thailand. Journal of Virus Eradication, 6(3), 100005. https://doi.org/https://doi.org/10.1016/j.jve. 2020.100005

Huo, H.-F., Chen, R., \& Wang, X.-Y. (2016). Modelling and stability of HIV/AIDS epidemic model with treatment. Applied Mathematical Modelling, 40(13), 65506559.

https://doi.org/https://doi.org/10.1016/j.ap m.2016.01.054

Jagannath, V., Unnikrishnan, B., Hegde, S., Ramapuram, J. T., Rao, S., Achappa, B., Madi, D., \& Kotian, M. S. (2011). Association of depression with social support and self-esteem among HIV positives. Asian Journal of Psychiatry, 4(4), 288-292. https://doi.org/https://doi.org/10.1016/j.ajp.2 011.10 .006

Jamil, K. F. (2014). Profil kadar CD4 terhadap infeksi oportunistik pada penderita human immunodeficiency virus/acquired immunodeficiency syndrome (HIV/AIDS) di RSUD dr. Zainoel Abidin Banda Aceh. Jurnal Kedokteran Syiah Kuala, 14(2), 7680.

Joint United Nations Programme on HIV/AIDS. (2014). Fast-track: ending the AIDS epidemic by 2030. Geneva. Switzerland: UNAIDS.

Joint, U. N. (2014). Programme on HIV/AIDS. The gap report. Geneva: Joint UN Programme on HIV.

Maartens, G., Celum, C., \& Lewin, S. R. (2014). HIV infection: epidemiology, pathogenesis, treatment, and prevention. The Lancet, 384(9939), 258-271.

Malaza, A., Mossong, J., Bärnighausen, T., Viljoen, J., \& Newell, M.-L. (2013).
Population-based CD4 counts in a rural area in South Africa with high HIV prevalence and high antiretroviral treatment coverage. PloS one, 8(7), e70126.

Mirzaei, M., Poorolajal, J., Khazaei, S., \& Saatchi, M. (2013). Survival rate of AIDS disease and mortality in HIV-infected patients in Hamadan, Iran: a registry-based retrospective cohort study (1997-2011). International journal of STD \& AIDS, 24(11), 859-866.

Montaner, J. S. G., Lima, V. D., Harrigan, P. R., Lourenço, L., Yip, B., Nosyk, B., Wood, E., Kerr, T., Shannon, K., \& Moore, D. (2014). Expansion of HAART coverage is associated with sustained decreases in HIV/AIDS morbidity, mortality and HIV transmission: the "HIV Treatment as Prevention" experience in a Canadian setting. PloS one, 9(2), e87872.

Olem, D., Sharp, K. M., Taylor, J. M., \& Johnson, M. O. (2014). Overcoming barriers to HIV treatment adherence: A brief cognitive behavioral intervention for HIV-positive adults on antiretroviral treatment. Cognitive and behavioral practice, 21(2), 206-223.

Rusconi, S. (2017). The impact of adherence to HIV/AIDS antiretroviral therapy on the development of drug resistance. Future Medicine.

Sidibé, M., Loures, L., \& Samb, B. (2016). The UNAIDS 90-90-90 target: a clear choice for ending AIDS and for sustainable health and development. Journal of the International AIDS Society, 19(1).

Turan, B., Smith, W., Cohen, M. H., Wilson, T. E., Adimora, A. A., Merenstein, D., Adedimeji, A., Wentz, E. L., Foster, A. G., \& Metsch, L. (2016). Mechanisms for the negative effects of internalized HIVrelated stigma on antiretroviral therapy adherence in women: the mediating roles of social isolation and depression. Journal of acquired immune deficiency syndromes (1999), 72(2), 198.

Turan, B., Rice, W. S., Crockett, K. B., Johnson, M., Neilands, T. B., Ross, S. N., Kempf, M.-C., Konkle-Parker, D., Wingood, G., \& Tien, P. C. (2019). Longitudinal association between internalized HIV stigma and antiretroviral therapy adherence for women living with HIV: the mediating role of depression. AIDS (London, England), 33(3), 571.

UNAIDS. (2020). HIV Prevention 2020 Road 
Map. https://www.unaids.org/sites/default/files/ media_asset/hiv-prevention-2020-roadmap_en.pdf

WHO. (2013). Consolidated guidelines on the use of antiretroviral drugs for treating and preventing HIV infection: summary of key features and recommendations, June 2013. World Health Organization.

WHO. (2013). Consolidated guidelines on the use of antiretroviral drugs for treating and preventing HIV infection: recommendations for a public health approach. Geneva: World Health Organization, 1-272.

WHO. (2015). Guideline on when to start antiretroviral therapy and on pre-exposure prophylaxis for HIV. World Health Organization.

WHO. (2016). Consolidated guidelines on HIV prevention, diagnosis, treatment and care for key populations. World Health Organization.

WHO. (2017). Kajian Nasional Respon HIV DI
Bidang Kesehatan Republik Indonesia. https://www.who.int/docs/defaultsource/searo/indonesia/non-whopublications/2017-hiv-country-reviewindonesia-bahasa.pdf?sfvrsn=76ccal118_2

WHO. (2020). HIV/AIDS. https://www.who.int/news-room/factsheets/detail/hiv-aids.

Yogani, I., Karyadi, T. H., Uyainah, A., \& Koesnoe, S. (2015). Faktor-faktor yang Berhubungan dengan kenaikan CD4 pada pasien HIV yang mendapat highly active antiretroviral therapy dalam 6 bulan pertama. Jurnal penyakit dalam Indonesia, 2(4), 217-222.

Young, J., Psichogiou, M., Meyer, L., Ayayi, S., \& Grabar, S. (2012). Opportunistic Infections Project Team of COHERE. CD4 cell count and the risk of AIDS or death in HIV-infected adults on combination antiretroviral therapy with a suppressed viral load: a longitudinal cohort study from COHERE. PLoS Med, 9, e1001194. 